\title{
Manizales años 1920: Arquitectura Republicana y vida urbana ${ }^{1}$
}

\author{
Manizales 1920's: Republican Architecture and Urban Life
}

\section{Rodrigo Santofimio Ortiz ${ }^{2}$}

\section{Resumen}

El presente artículo tiene que ver con la investigación Trazos de vida urbana en la ciudad de Manizales años 1920-1930; aquí referimos al ornato urbano, en tanto propósito estratégico de rediseñar la ciudad de acuerdo a cánones civilizatorios y de progreso ínsitos en la modernidad, y en ese caso, las nuevas clases sociales. Mirando a Europa, se planteó no solo la arquitectura Republicana, sino también modificar la traza urbana y una nueva forma de habitar la ciudad; en los años 20, Manizales no se sustrajo a esos procesos, pero los incendios, la actitud de los agentes sociales y las formas fascistoides, hicieron que el proceso fuera merecedor de particular atención. El método se apoyó en la historia cultural urbana con aportes de Almandoz, Romero y Uribe.

\section{Palabras clave}

Historia urbana, Manizales, vida urbana, arquitectura republicana, vivienda urbana.

\begin{abstract}
This article relates to the investigation Trazos de vida urbana en la ciudad de Manizales años 1920-30 (Traces of urban life in the Colombian city of Manizales between 1920 and 1930). Here we refer to the urban ornament as a strategic purpose of redesigning the city according to civilizing and progress canons inherent in modernity and, in that case, the new social classes. Europe was the referent to adopt no only the republican architecture but also to modify the urban layout and a new way of inhabiting the city. In the 1920s, Manizales did not escape these processes, but events such as the fires, the attitude of the social agents and the fascistic forms made them worthy of particular attention. The method utilized based on urban cultural history with contributions from Almandoz, Romero and Uribe.
\end{abstract}

\section{Keywords}

Urban history, Manizales, urban life, republican architecture, urban housing.

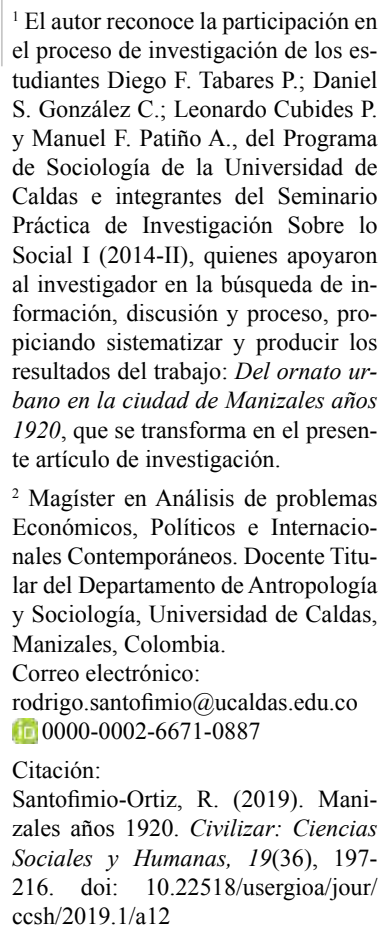

${ }^{1}$ El autor reconoce la participación en el proceso de investigación de los estudiantes Diego F. Tabares P.; Daniel S. González C.; Leonardo Cubides P. y Manuel F. Patiño A., del Programa de Sociología de la Universidad de Caldas e integrantes del Seminario Práctica de Investigación Sobre lo Social I (2014-II), quienes apoyaron al investigador en la búsqueda de información, discusión y proceso, propiciando sistematizar y producir los resultados del trabajo: Del ornato urbano en la ciudad de Manizales años 1920, que se transforma en el presente artículo de investigación.

${ }^{2}$ Magíster en Análisis de problemas Económicos, Políticos e Internacionales Contemporáneos. Docente Titular del Departamento de Antropología y Sociología, Universidad de Caldas, Manizales, Colombia.

Correo electrónico:

rodrigo.santofimio@ucaldas.edu.co (iD) 0000-0002-6671-0887

Citación:

Santofimio-Ortiz, R. (2019). Manizales años 1920. Civilizar: Ciencias Sociales y Humanas, 19(36), $197-$ 216. doi: 10.22518/usergioa/jour/ $\operatorname{ccsh} / 2019.1 / \mathrm{a} 12$ 


\section{Introducción}

En las últimas dos décadas, los estudios de Historia Urbana vienen cobrando importancia en Colombia gracias a trabajos que, si bien permanecen en la perspectiva económica, muestran las formas de vida que acontecieron en ese estadio de lo que Uribe (1984) denominó la reproducción del capitalismo: el emergente proceso de industrialización simultáneo a la urbanización de algunas ciudades en Colombia a finales del siglo XIX y las primeras décadas del siglo XX; entre ellas la moda y el esteticismo que inspiraron a la naciente burguesía local, así como sus ideales y representaciones en el interior de esas nuevas ciudades. En ese sentido, los trabajos de Botero(1996), Urrego (1997), Mejía (2000), González (2006) y Correa y Martínez (2010), por solo mencionar algunos, expresan el interés por una sub-disciplina que, más allá de focalizar la industrialización y la urbanización a secas, ahonda en lo que Almandoz(2008) expuso como la historia cultural urbana, esto es, el detallado cadre de vie de un lugar, personajes o episodios para comprender «la significación de esa época, con su mentalidad y categoría social», o «el corazón de una realidad histórica, la globalidad de la unidad». Para nuestro caso, Latinoamérica, Almandoz (2008) señala:

La explicación de las formas de representación parece ser especialmente necesarias, cuando más que investigar los orígenes de la urbanización en su dimensión demográfica o del urbanismo en su sentido técnico, se intenta indagar la formación de la cultura urbana y el despertar de la conciencia sobre la ciudad en una sociedad. (p. 187).

Así pues, cuando el análisis intenta retrotraerse hasta antes de los orígenes del urbanismo moderno en los comienzos del siglo XX, expresa Almandoz:

Hace falta entonces traducir este vocablo a sus antecedentes históricos: ciudad, progreso, civilización, ornato urbano (o recurrencia al esteticismo, diríamos nosotros), higiene, entre otros, para poder así nutrirse de los diversos discursos de los que ha surgido esa disciplina en muchos contextos nacionales. (2008, p. 211).

En ese contexto, estimamos que el trabajo Los años veinte en Colombia. Ideología y cultura, del sociólogo Carlos Uribe Celis (1984), inicia el giro urbano para mostrarnos que los 20:

Son años de urbanización $(U r b s=$ ciudad $)$, son años de "civilización" ( civitas = ciudad); la civilización, en efecto, nos invade con aquellos productos cuya sola presencia no puede menos que cambiar la mentalidad total de un pueblo: el avión, el automotor, el cine (cinematógrafo), la radio (radiófono), producen mentalidades correlativas, nuevos modos de ser, de vivir y de pensar; el capital es amigo exigente; requiere actitudes propias y entregas totales: hombres nuevos. (p. 26).

Si bien la obra en mención es profusa en detalles de todo ese universo que significó el paso decisivo hacia la modernización del país, no se atiene a los procesos y experiencias para cada una de las ciudades que empezaron a despegar en el ámbito nacional y solo admite que allí, esto es, en las ciudades, dice Uribe: "nuestra tendencia a crear resultó ser muy reducida, en tanto que la dirigida a imitar es protuberante" (1984, pp. 132-133).

Todas y cada una de las ciudades en Colombia, y la élite o burguesía en su interior, adquirieron lo que Ginzburg (1989) llama el $c a$ rácter particular como dimensión histórica. Lo hicieron con el propósito de ordenar, disciplinar y orientar en ese nuevo espacio que connotó y definió a la ciudad bajo el presupuesto de unas nuevas relaciones sociales de producción y, con ellas, ciertos dispositivos ideológicos (representaciones). Fueron ellos la idea de civilización y progreso, el ornato urbano y la estetización de la vida social; la higiene, la impronta del individuo o ciudadanización; las sociabilidades o el altruismo -como se denominó para la época-, entre otros cánones que irrigaron la nueva trama social y urbana que se inauguró. 
También hizo parte de estas representaciones la manera en que se respondió ante la iniciativa de la industrialización, lo que ciertamente derivó en resolver el fenómeno de la urbanización o de lo lleno. Dice Bardet: "todo está lleno. Nada es lo suficientemente grande como para contener a las muchedumbres: ni las ciudades, ni los edificios, ni las plazas" (1961, p. 5). Otro tanto ocurrió con la circulación, el problema de la higiene y el confort, los problemas económicos y sociales y, por supuesto, los problemas intelectuales y espirituales.

Ahora bien, si nos quedásemos con la comprensión imitativa del fenómeno urbano que vivieron las ciudades, en particular la Manizales de los años 1920, ese acercamiento cabe sin duda en la dimensión más analítica del capitalismo. Empero, a riesgo de traslapar, incluso negar ese carácter particular como dimensión histórica, resulta importante revisar, analizar y comprender aquel momento histórico de Manizales en los años 20, a la luz de dichas relaciones sociales de producción y sus dispositivos ideológicos. Pretendemos, entonces, en este propósito de historia urbana, acercarnos al ornato urbano en la medida que significó el interés de transformar ese nuevo espacio por otro, y ello requirió plantear una concepción de ciudad, un estilo y unas estéticas para ciertas clases sociales y grupos en dicha etapa del capitalismo de la industrialización y la competencia.

\section{La Ciudad de Manizales y los incendios de 1922, 1925 y 1926}

Botero sostiene que los incendios de la ciudad de Medellín en los años 1920 estaban relacionados con los cambios urbanos suscitados en esos años, así como "del factor especulativo, que estaba íntimamente ligado a ese imaginario de ciudad" (1996, p. 197); para el caso de Manizales, además de la conmoción que ocasionaron los tres siniestros de 1922, 1925 y 1926, es preciso señalar que esas conflagraciones tuvieron un origen directo con la textura urbana de las edificaciones, los materiales de que estaban construidas y, por supuesto, las actividades que se llevaban a cabo al interior de las viviendas, como la fabricación de fósforos y velas de parafina, tiendas de comestibles, en donde incluso "se almacenaban además de drogas, municiones para armas de fuego" (Valencia, 1990, p. 48); al igual que Gaviria (1924), quien alude a este tipo de fábricas y adiciona las fundiciones y cerrajerías y, de acuerdo a Fray Pedro Fabo de María, funcionaban tres fábricas de velas y una de fósforos. Cabe mencionar que no toda la responsabilidad de los incendios se atribuían a las condiciones de las viviendas, pues también se aludía a que el "mal estado de las líneas eléctricas; "Es increíble»" (La Patria, 28 de septiembre, 1922, p. 1). Muchas de esas viviendas eran "estructuras de madera con techo pajizo o instalaciones más estables en tapia y teja de barro" (Escobar, 1997, p. 56). Por su parte, Robledo (1997) definía estas viviendas como:

Ranchos de vara en pie, con techos de paja o de corteza de cedro los que hoy se pudieran definir con el genérico nombre de bahareque, edificios no sólo susceptibles a cualquier conato de incendio, sino también de riesgo frente a los embates de los terremotos. (pp. 71-72).

Por tanto, si este período anticipó futuras transformaciones urbanas a nivel de edificaciones, esto se constituyó no solo como lo plantea Botero (1996), del interés urbanizable de la ciudad, sino también como la idea de probar partir de la incorporación del concreto armado, con edificios firmes y compactos que evitaran el riesgo de nuevos incendios. Ciertamente el experimento funcionó, pues además de plantear un formato de arquitectura que privilegiaba el cemento, se adicionaron materiales no combustibles. Incluso se ampliaron las distancias que debían guardar las edificaciones entre sí, lo que derivó en otros usos para las calles y carreras, medidas bastante oportunas que reclamaban los vehículos de ruedas; y se insinuó la "arquitectura geométrica con la incorporación de la ochavada para las nuevas edificaciones, permitiendo [sic] mayor visibilidad tanto para los conductores de vehículos como para los transeúntes" 
(Escobar, 1997, p. 60)1. Esta interacción permitió otra forma de relacionar al transeúnte con los conductores: los primeros caminaron por las aceras que, por supuesto, cobraron la debida importancia; y las calzadas para los conductores, por cierto, no exentas de dificultades como lo muestra una nota periodística de esos años:

Parece mentira, pero ya es materialmente imposible transitar por la calle de la Esponsión, nuestra única arteria de ruedas. La actual configuración del terreno saca a los vehículos de madre y los echa a rodar por los pavimentos dando [sic] casi de narices contra los edificios y poniendo $[s i c]$ en gran aprieto a los peatones que transitan por la vía. Sobre todo los niños peligran. (La Patria, 8 de abril de 1922, p. 1).

Así, la organización espacial de la ciudad cobró sentido no por obra y gracia de los incendios, ciertamente "aliados de los promotores del progreso y la modernización" (Esguerra, 1997, p. 82), sino por ese afán modernizador que se reclamó para la ciudad capital, por lo que los incendios no hicieron más que acelerar dicha intención. Así mismo cabe decir que los incendios intrínsecamente llegaron a poner en discusión las posibilidades de continuar con el ideal de emplazar una ciudad en esa topografía. Como lo sugiere Fu Tuan (2007) para otro contexto, se trataba de "poner en marcha un ideal, así como un estilo de vida total que se plasmase en patrones espaciales, en formas arquitectónicas y en escenarios materiales en este rincón del mundo" (p. 233). En ese propósito, las fuerzas económicas y sociales contribuyeron de forma decisiva a constituir "estilos de vida", pero como plantea Fu Tuan, "puede hacerse de manera inconsciente", no así los "impulsos idealistas" que en comunidades relativamente integradas pueden encontrarse expresadas de forma material y a gran escala" (2007, p. 234). Se insistió así en ese ideal para reafirmar un propósito y no renunciar a constituir la ciudad, la "ciudad civilizada", aún de cara a las adversidades:

El fuego estalló en la cocina de la casa del señor Joaquín Gómez en cuyo tejado se notaron las primeras llamas. También se ha creído generalmente que pudo ser en la fábrica de velas "La Campana", situada en la calle 14, entre las carreras 10 y 11 (...) fue el doctor Ricardo Jaramillo Arango: dando gritos de auxilio a los vecinos, consiguió reunir gente que le ayudaran [sic] en su obra de salvación y que hicieran tocar plegaria (...) Entre nueve y diez de la mañana pudimos ver aplacado el fuego que tan emocionante cuadro dejaba expuesto y que será, como al principio dijimos, de memoria eterna a la vida de nuestra floreciente y noble capital. (La Patria, 22 de julio de 1922, p. 1).

Como es natural, en ese incendio hubo "un crecido manoteo en que actuaron muchos rateros", dice la nota periodística; la policía lució una vez más gran habilidad así como honorables caballeros y niños que no escasearon en vigilancia para proteger la propiedad ajena. La solidaridad también se expresó en unos "maestros y niños excursionistas", quienes venidos de Riosucio, Pereira y Aguadas, fueron sorprendidos por el desastre, sin embargo hicieron "gala de sus buenos sentimientos y filantropía" ayudando a la extinción del flagelo con lo que caía en sus manos. La ciudad no estaba materialmente preparada frente a la magnitud del desastre, carecía de bombas extintoras suficientes e hidrantes y más aún de un voluntariado con personas capacitadas en la tarea de extinguir incendios.

El Consejo municipal, entre otras disposiciones, insistió en que los propietarios de los inmuebles recurrieran al seguro de sus edificios, depósitos, almacenes, etc., como medida de prudencia y como defensa anticipada de los perjuicios materiales que trae consigo una calamidad. Sin embargo, la persistencia en el ideal de constituir "el organismo de la urbe naciente y civilizada", lo tradujo en ese momento la nota periodística que pocos días después del siniestro hiciera Silvio Villegas, invocando para Manizales "su futura grandeza", e insistir en el ideal traducido con fervor místico -puro y sencillo-de clarísima ascendencia castellana: 


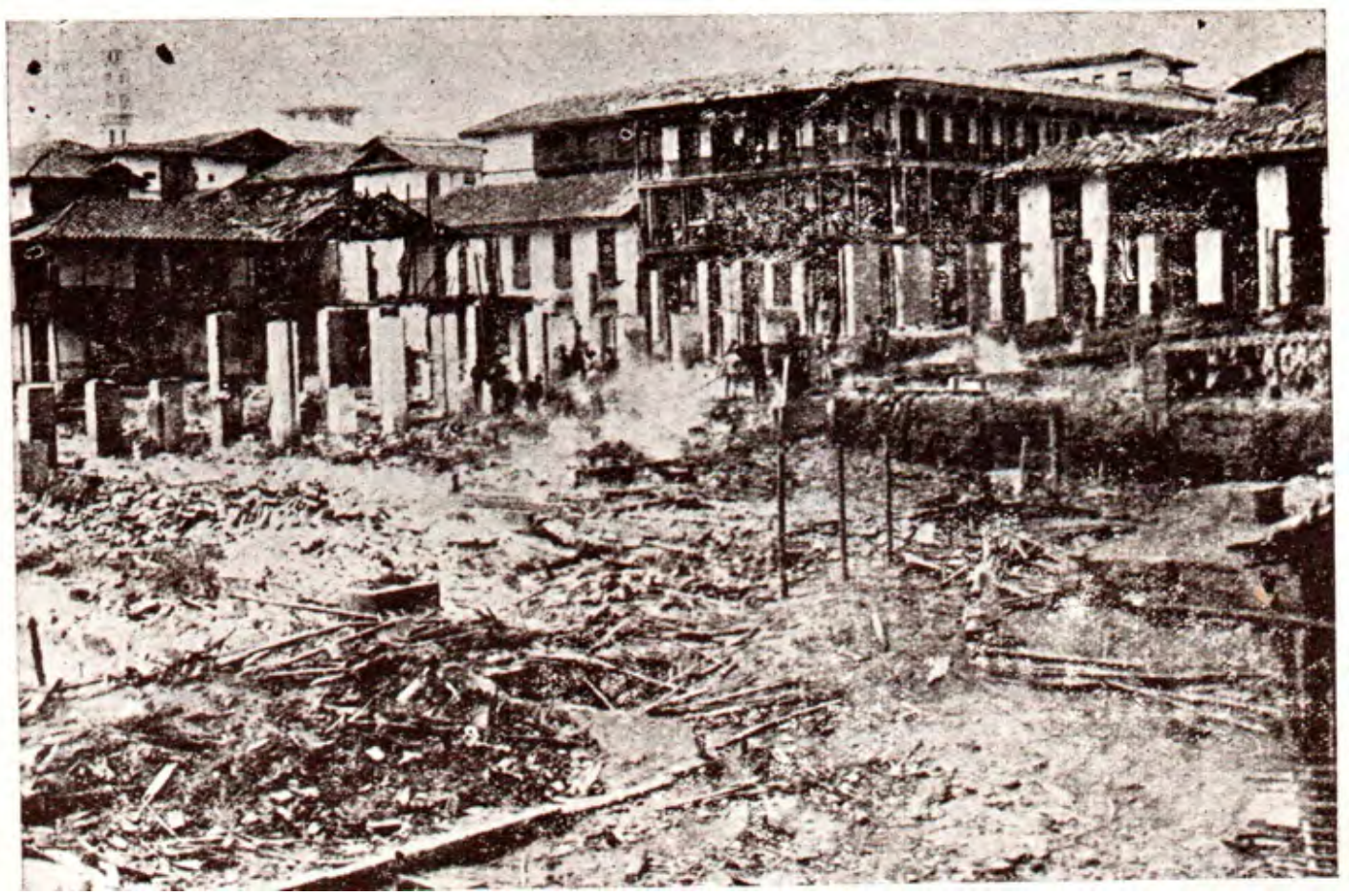

Figura 1. Incendio de 1922. Fotografía tomada de Historia de la ciudad de Manizales, por P. Fabo de María, 1926, p. 251.

Manizales, definitivamente, no será jamás víctima del fuego propiciatorio de los dioses (pues) en continuo devenir, de ella puede decirse que cada diez años se renueva, hasta el punto de no conservar ni pedazos de su existencia anterior. El fuego -el dios tormentoso de la vida y de la muerte- ha desgarrado ahora sus entrañas mismas de la ciudad amada. Que esta aspereza lamentable sea para ella por reflejo, tan sólo el albur de un futuro gloriosísimo. (La Patria, 29 de julio, 1922, p. 5) 2 .

El otro siniestro que avivó aún más la voluntad y el interés por un ideal para la constitución de la ciudad moderna, aconteció el 3 de julio de 1925, cuando:

A las diez de la noche el tañido de las campanas de la iglesia produjo un pánico general (...) el incendio sólo se detuvo a la mañana del día siguiente, pero las ruinas siguieron ardiendo durante ocho días más: se habían destruido 229 edificios en 32 manzanas; la conflagración fue de tal magnitud que se tuvieron que destruir con dinamita edificios alrededor del incendio con el fin de tender un anillo de campo raso para aislar el fuego. (Valencia, 1997, pp. 49-50).
El siniestro puso en consideración la continuidad de la capital departamental teniendo en cuenta que Pereira, a cincuenta kilómetros de distancia e importante ciudad comercial, ya le competía a Manizales ${ }^{3}$; sus dirigentes la propusieron ante el presidente General Pedro Nel Ospina "para que se trasladara la capital del Departamento a esa ciudad", pero él respondió que "Manizales en cenizas seguirá siendo la capital de Caldas" (Valencia, 1997, p. 50). Correlativo a ese pronunciamiento del presidente, al día siguiente de la calamidad, convocados por el alcalde y el personero, los ciudadanos iniciaron la remoción de escombros, para lo cual acudieron "todos los sectores sociales con herramientas en mano a preparar el terreno y dejarlo listo para la reconstrucción de la ciudad" (Valencia, 1997, p. 50).

Es de notar que la magnitud del incendio quedó registrada en lo que Salazar(2012) intituló "la revista fílmica", esto fue, el documental urbano Manizales City, y que por esos años se difundió para mostrar las evidencias del 
progreso y la cultura a través de actividades como el carnaval y los bailes, así como los grandes y hermosos edificios modernos, lo que hizo ver "como una de las ciudades más progresistas del momento" (pp. 117-118) ${ }^{4}$.

Meses después, la visita del ministro Marulanda al lugar de la conflagración permitió dimensionar la situación que se vivía en la ciudad:

Cuando llegué a la ciudad me sobrecogí ante la vista de la magnitud de la catástrofe; la había considerado de proporciones menores. $\mathrm{Me}$ pasó como cuando se encuentra uno al frente de un problema que no es de resolver. Creí en un momento que fallaban mi entusiasmo y $\mathrm{mi}$ fe; pero mi entusiasmo y mi fe son superiores al esfuerzo que requiere la reconstrucción de Manizales. (La Voz de Caldas, 19 de enero, 1926, p. 1) $)^{5}$.

El entusiasmo que rezuma, al final, la intervención del ministro Marulanda fue traducido seguidamente, de acuerdo con J. Palex, colaborador del periódico La Voz de Caldas, como "espíritu valeroso que forma el alma colectiva de Manizales, espíritu que nació y se templó al fragor de la llamarada", por tanto, el entusiasmo y la fe, serían "lábaros de la reconstrucción de Manizales, con ellos asistiremos al triunfo" (La Voz de Caldas, 19 de enero de 1926, p. 2).

No cabe duda de que el punto de inflexión en la reorganización urbanística de la ciudad fue ese hito del siniestro de 1925, que puso un sello netamente moderno a la textura urbana, esto es, un semblante republicano a prueba del fuego y los terremotos, al iniciarse la reconstrucción de Manizales que congregó a sectores sociales de diversa índole: industriales, comerciantes, políticos y la prensa escrita, así como al ciudadano del común. La iniciativa más importante fue el contrato hecho con la Ulen \& Company del Estado de Delaware (Estados Unidos), avalado por los gobiernos nacional, departamental y municipal, quienes firmaron la póliza respectiva en la que sustantivamente "La Compañía" haría varios edificios en la ciudad, incluso también el acueducto, alcantarillado, pavimentación de las calles, reparación y mejora de la plaza de mercado y la plaza para la venta de carnes; "La Compañía", también ensancharía la planta de energía eléctrica para aumentar el alumbrado, entre otras obras, en síntesis, había que construir, dice Esguerra:

Doscientos edificios: palacio de la gobernación, nacional y episcopal, los bancos y hoteles importantes de la ciudad; los destinados a viviendas y negocios de varios de los grandes y medianos comerciantes, cafeteros y ganaderos de Caldas; como también la casa de habitación de muchos tenderos y artesanos cuyos recursos económicos estaban limitados exclusivamente a estas actividades. (1997, p. 90).

El coste de la reconstrucción se calculó en cuatro millones de dólares, es decir, comparable al coste de la ruta ferroviaria Cartago - Pereira, multiplicada por dos, que tanto se publicitó para la época ${ }^{6}$; se constituyó una junta compuesta por miembros del nivel nacional, departamental, municipal y también del sector privado, que se llamó Junta de Reconstrucción de Manizales y tendría por funciones de interventoría para "la ejecución del presente contrato", empero, llegó a objetarse el que "La Compañía" cobrase el 7\% de comisión anticipadas por los dineros que se recibieran de las Casas Aseguradoras, "sin haber siquiera dado principio a los trabajos preliminares de cada edificio que va a reconstruirse" (La Voz de Caldas, 21 de enero de 1926, p. 3).

Las objeciones al contrato que proponía "La Compañía", fueron expuestas por los dos periódicos importantes de la ciudad, La Patria y La Voz de Caldas, expresándose en términos de un "No al monopolio de la Ulen" (Esguerra, 1997, p. 94); dada la dificultad que afectaba, según se infiere, a sectores de medianos y pequeños comerciantes, el periódico $L a V o z$ de Caldas hizo una consulta a los lectores en la que planteó durante algunos meses la siguiente inquietud: “ ¿Es conveniente para los particulares y la ciudad en general el contrato de Re- 
construcción con la Ulen?” (1926, p. 1.). Varios personajes, miembros conspicuos e importantes de la ciudad manizaleña participaron de la consulta para coincidir en que resultaba "rápido, bien y barato" la participación de "La Compañía", pues, diría Aquilino Villegas, se privilegiaría la construcción en:

Materiales incombustibles para que dentro de dos o tres años tuviéramos la más bella de las ciudades, levantada para la permanencia de los siglos y no el campamento de beduinos hecho de guadua y otras sustancias mal olientas [sic] presa propicia para el fuego, la broma y la humedad. (La Voz de Caldas, 28 de enero de 1926, p. 1).

Silvio Villegas terció en la consulta abierta por el periódico para expresar la conveniencia en el contrato de reconstrucción con la Ulen "por su probada experiencia en edificaciones modernas; las cotizaciones exactas que dan los ingenieros de la Ulen del costo", eso sí, agregaba Aquilino: "poniéndonos en frente como censores capacidades técnicas y morales de primer orden" (La Voz de Caldas, 3 de febrero de 1926, p. 3) 7 .

Se iniciaba entonces, la era del concreto armado con la participación de "La Compañía" para la reconstrucción de Manizales lo que hizo posible, construir la ciudad para los automóviles, la ciudad del progreso sin "anti-estéticos aleros", la metrópoli del futuro, una ciudad, "que sea el modelo de una ciudad moderna que sirva para mostrarla al pueblo colombiano" (Esguerra, 1997, p. 93), en lo que coincide Uribe (1984) al decir que: "Manizales en sus años veinte es un orgullo nacional tras la reconstrucción de la Ulen".

Sin embargo, el incendio del 20 de marzo de 1926, ocho meses después de la conflagración que hiciera temer en las posibilidades de constituir la ciudad capital, retrajo los temores más pesimistas sobre el futuro de grandeza de la ciudad, incluso sobre su propia existencia, toda vez que el fuego en esa oportunidad, afectó "las zonas más importantes del centro en donde está situada la riqueza", y porque con ese incendio "la iglesia catedral quedara en escombros", así que: "Dios parece que quisiera probar nuestra fe, nuestra creencia en él, nuestra resignación, nuestra energía, nuestro esfuerzo, nuestra confianza en su bondad y en su justicia" (La Voz de Caldas, 21 de marzo de 1926, p. 1).

En esta oportunidad, dice Valencia (1997), se destruyeron 20 edificios que albergaban almacenes, oficinas y casas de habitación; los talleres de La Patria quedaron reducidos a cenizas; la nota periodística que siguió el acontecimiento con detalles diría:

A las cinco de la mañana del sábado $20 \mathrm{de}$ marzo, la ciudad todavía estaba tranquila. En la iglesia catedral decía misa, el Padre Zuluaga quien daba, además la bendición nupcial a una sencilla pareja de novios. El salir los fieles de la iglesia, vieron con ojos sorprendidos que las llamas salían ya a la calle, amenazadoras por la parte oriental del suntuoso edificio del Centro Social (...) Estaba ya terminado el edificio del Centro Social y había empezado a arder con su fuerza inusitada la casa de los herederos de Don Francisco Vélez (...), y de ésta las llamas pasaron a la iglesia catedral quedando en pocos momentos envuelta en humo negro, como si estuviera teñida de aceite, la cúpula de la iglesia (...) La emoción en esos momentos fue extraordinaria en todo el mundo. La angustia en los rostros se retrató. Las lágrimas florecieron en los ojos de todos. Todos estaban unidos a esa casa querida, la casa de Dios (...) Por fin el fuego (...) se trepó a lo más alto de la encumbrada torre, hincó su aguda punta rojiza sobre los brazos de la cruz, sonaron algunos golpes trémulos del viejo campanario y se desplomó el maderamen. (La Voz de Caldas, 21 de enero de 1926, p. 2).

De acuerdo con los bomberos, el incendio se localizó en "las droguerías Unidas, frente al círculo del comercio". La cercanía de los edificios (a través de los aleros), la brisa o vientos que soplaban y por supuesto, los materiales 
combustibles propiciaron su propagación. Si bien la ciudad contaba con un cuerpo de bomberos, también era cierto que más allá de la heroicidad con que atendieron el siniestro, carecían de elementos de dotación para intervenir con mayor efectividad; las pérdidas, incluyendo los objetos valiosos al interior de la iglesia catedral, se calcularon alrededor de un (1) millón de pesos; las pólizas de seguros cubrían hasta trescientos mil pesos y la iglesia catedral no estaba asegurada 9 .

Mencionar que luego del incendio el desconcierto fue general como se deriva del ambiente que tradujeron no solo la prensa, sino también uno de los actores presentes:

Cuando una mañana, nuestra campana -la nuestra, la más sonora y cristalina que jamás oímos- gritó su grito de angustia que se fue saltando sobre los tejados y sobre las ruinas (del anterior incendio). Otra vez el incendio, otra vez la brega, desesperada. (Versión de Aquilino Villegas, citada por Valencia, 1997, p. 50).

Ahora no solo era reiterativa la amenaza sobre la ciudad, que parecía incluso también arrebatar los fundamentos de la fe y la esperanza que representaba la iglesia catedral, puesto que el espíritu y los ideales encarnados en el proyecto de constituir la ciudad capital, parecían desvanecerse en ese instante con ella en escombros. Para parodiar la alusión que hace Harvey para la sociedad postmoderna, "en que allí se reafirma la verdad de Dios, sin abandonar los poderes de la razón" (2004, p. 54), nosotros diremos que en esa oportunidad con ese incendio llegado de manera menos oportuna, los poderes de la razón no estaban mejor salvaguardados que la verdad de Dios, es decir, que el proyecto de la ciudad así como la voluntad en Dios, todo parecía envuelto en "humo negro", tal cual quedó la cúpula de la iglesia: y la angustia en los rostros se retrataba.

"Castigo de Dios", "manos criminales", "intereses de fuera" u "odios regionales", fue- ron las cavilaciones que sobrevinieron a fin de intentar descifrar las posibles causas del siniestro ${ }^{10}$; sin embargo, las versiones más autorizadas concluyeron que hubo negligencia y descuido con materiales inflamables, dado que aparecieron fogones de viruta, los que supuestamente se manipularon con una porción de fósforos, que también fueron hallados en el sitio de la conflagración, lo que pudo haber originado el incendio; a partir de esos registros periciales llegó a plantearse la hipótesis de "movimientos criminales", por lo que el periódico La Voz de Caldas hizo eco sobre la supuesta provocación del incendio por "manos criminales", y coligiendo que de ser verídica la hipótesis, "el linchamiento nos parece poco" (La Voz de Caldas, $1^{\circ}$ de marzo de 1926, pp. 3; 6).

Sin embargo, tal supuesto más que sugestivo no pasó a mayores, dado que aún sin obrar con intención criminal, cualquier "peón o caballero" podía llevar en sus bolsillos el agente destructor, esto era, el cigarrillo, el tabaco, los fósforos, los cuales dadas las condiciones de la ciudad la hacía más vulnerable, aún con ese sencillo acto de "arrojar al suelo una colilla de cigarrillo o una cerilla encendida"; era pues evidente que la angustia del momento llegó a percibirse e interpretarse no sólo como un "acto de incivilidad", sino también como: "un grande atentado contra la seguridad social", mejor dicho contra la ciudad ${ }^{11}$.

Así las cosas, se constituyó de inmediato La liga de acción y defensa de Manizales, cuyo presupuesto de acción derivaba de interpretar que "los derechos colectivos deben primar sobre los individuales", y que "los intereses permanentes de nuestra ciudad valen más que los de cada uno de sus componentes", y en ese caso "estamos resueltos a imponer por todos los medios a nuestro alcance así como en la gestión pública-legislativa y ejecutiva-como en el desarrollo de las actividades particulares en cuanto puedan afectar los intereses colectivos", por tanto, concluía la nota editorial: "combatiremos a los particulares que pretendan interponer su 
intereses a los de la colectividad" (La Voz de Caldas, 24 de marzo de 1926, p. 2).

Se observa, entonces, el nivel alcanzado en los ánimos que expresa la "Liga" a manera de cruzada se disponía a emprender acciones contra los particulares que pusieran en riesgo el proyecto civilizatorio de la ciudad, es decir, su avance y progreso; la cota en ese estado de angustia y desazón que parecía poner los semblantes en máxima tensión y disposición de alerta, frente a cualquier propósito de atentar contra la ciudad, se alcanzaba, sin duda, con la destrucción de la Iglesia catedral, que dejaba a esos hombres sin resguardo espiritual, de esperanza y de fe; a la manera en que alude Argan, refiriéndose a la ciudad como "espacio visivo", la ciudad "no está hecha de piedras sino de hombres, pues son los hombres quienes le atribuyen un valor a las piedras" $(1984$, p. 28$)$. De hecho, el valor de una ciudad es el que le atribuye toda una comunidad, de tal forma que los hechos arquitectónicos, en nuestro caso, la iglesia catedral, se experimentan no solo funcionalmente, esto es, a partir de su razón de ser -lugar para el culto y la ritualidad-, sino también como un punto de valor, una especie de topos privilegiado que, más allá de su funcionalidad, se percibe y se juzga: "lo vivo en su dimensión funcional o lo contemplo, quedándose como imagen sedimentada en los diversos niveles de la memoria: esas imágenes pueden ser visivas o auditivas y, como todas las imágenes, pueden ser mnemónicas, perceptivas o eidéticas (o morales)" (Argan, 1984, pp. 219; 222).

Aquello parece explicar los ribetes que alcanzaron las exhortaciones para la defensa del interés colectivo y su acción solidaria, que llegaron a traducir expresiones de contenido fascistas. Se daba a entender que, de cara a la asociación o interés colectivo (la ciudad en este caso) relegado a un orden inferior (es decir, un pueblo ferozmente individualista), era preciso, entonces, sustraer o negar cualquier derecho individual o corporativo que pusiese en riesgo aquellos derechos, en ese caso, los de la ciudad y su supervivencia y por supuesto, su referente más caro, la iglesia catedral; acotar en ese sentido que la ciudad de manera análoga a la iglesia, alude Contardi, "es representativa de un valor ideológico" (1984, p. 6); así que nunca estuvieron más en riesgo esas dos identidades: pues el ser ciudadano presupone intrínsecamente a la ciudad a través de ese sentimiento espacial de la ciudad o sentimiento visivo, pero también un sentimiento hecho de relaciones asociativas y como partícipes de una comunidad de valores, esto es, la fuerza de la fe religiosa, por lo que cualquier salvaguarda a esos valores que expresan la identidad, cualquier recurso era menester, incluido, claro está, el reclamo desde la postura fascista:

El honor es para el soldado fascista una ley severa, de justicia absoluta, aunque tenga que pasar por encima de la ley escrita formal. Es lo que nosotros necesitamos en esta hora de serias amenazas: ir contra la ley escrita cuando ella sólo sirve para amparar el propósito anguloso de quienes se constituyen en obstáculos del progreso y en peligros contra la seguridad social (La Voz de Caldas, 25 de marzo, 1926, p. 1).

Una de las decisiones que emergieron en esa disposición y aliento con claro acento fascista, tiene que ver con la creación y nombramiento de un Inspector de canalización eléctrica, adscrito o dependiente de la inspección de Policía de Seguridad. Entre sus funciones, no solo inspeccionaría las canalizaciones eléctricas dentro del área de la ciudad, tanto en las calles como dentro de los edificios, sino que también haría inspección de "las cocinas, trilladoras, fábricas y demás establecimientos que puedan ser causa de incendio y velar porque en ellos se cumplan las disposiciones de la Inspección de Policía de Seguridad"; correlativo a esa disposición de vigilancia, el "cuerpo de bomberos", ahora remozado con más miembros, se encargaría también de la "vigilancia nocturna en la ciudad, especialmente en la parte ocupada por el comercio, a fin de dar aviso inmediato de todo caso de incendio que se presente" ( $\mathrm{La} \mathrm{Voz}$ de Caldas, 26 de marzo, 1926, p. 1) $)^{13}$. 
Se debe advertir que las expresiones y actitudes fascistas no fueron extrañas en este ambiente de emergencia y relativa consolidación del nacionalismo, como empeño ideológico adicional al del progreso y la civilización que aguardan el despliegue de las ciudades en Colombia (Uribe, 1984). Manizales no fue la excepción. Sin embargo, lo particular en este caso fue que dichas actitudes fascistas hundieron raíces, de un lado, en el carácter conservador de la sociedad manizaleña para la época: carácter constituido al tenor y refriega en el siglo XIX e inicios del XX, contra su alter-ego, el partido liberal, al concebirlo como estimulador de "las pasiones y los apetitos del pueblo (...) para volcar el orden establecido" (La Patria, editorial, 28 de abril de 1922, p. 1) ${ }^{14}$; de otro lado, la actitud fascista se ajusta al ambiente local, en el sentido de apremios y angustias que se suscitaron para reconstruir la ciudad capital y, ciertamente, el baluarte en ese propósito tiene que ver con el papel e incidencia de la iglesia en la vida social, la cual no solo llegó a verse amenazada por riesgos materiales, sino también que éstos mismos parecen traslaparse causalmente en el partido liberal, el bolchevismo y el socialismo.

No era casual que el periódico La Patria, hiciera eco para la época de la interpretación que se tenía del fascismo al justificarlo porque:

Ante la impotencia del gobierno para amparar a los dueños, Benito Mussolini organizó la defensa violenta entre todos los que tenía algo que perder de las violentas acometidas de los bolseviques $[\mathrm{sic}]$. De allí nació el fascismo, organización debida a la iniciativa privada para atacar a los comunistas allí donde se reuniesen, (...) en una palabra la organización de la revancha contra el socialista violento, absorbente y agresivo. Toda la parte sana de la sociedad italiana, sin distinción de partidos, pertenecen al fascismo, que es hoy el enemigo más formidable con que tiene que luchar el socialismo bolsevique [sic]" (La Patria, 15 de mayo de 1922, p. 1).

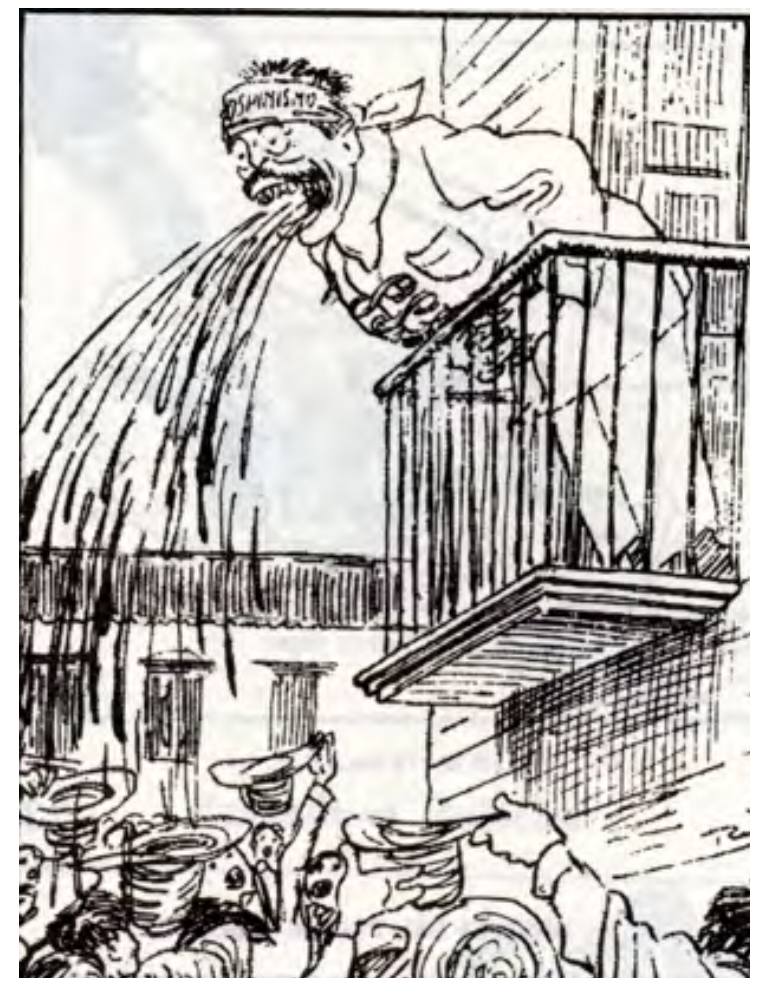

Figura 2. Aquilino Villegas. Tomada de Ricardo Rendón: Una fuente para la historia de la opinión pública, por G. Colmenares, 1998, p. 46.

De momento no ahondaremos en las posturas fascistas que expresaron sectores de la sociedad de cara a una situación difícil de la ciudad, solo diremos sobre ese aspecto que autores como Ocampo (1972) aluden a las ideas falangistas y corporativistas en esos años a través de uno de sus personajes. Por su parte, Uribe (1984) logra ubicar estas expresiones en el ámbito del flujo de las generaciones ínsitas a las ciudades para los años veinte en Colombia; y Tirado, describe al fascismo en Colombia como fuerzas organizadas: "las derechas del partido de la derecha", las cuales confrontan el primer gobierno de López Pumarejo y llegan también a discutir la preeminencia al jefe del partido conservador Laureano Gómez (1889-1965), viendo en él "un encarnizado rival, un enemigo acérrimo al que se enfrentarán en innumerables ocasiones a lo largo de toda su vida política" (1995, p. 297); por último, Tirado muestra que la fuerza de esas organizaciones estaban en departamentos como Caldas y Antioquia; en lo 
que respecta al fascismo como tipo ideal en su despliegue europeo, diríamos que para el caso de Italia, tiene un origen rural y urbano con "aquellos campesinos no integrados y los efectos de la Gran Guerra en las ciudades" (Payne, 1995, pp. 122-123), y en el caso de Alemania el fascismo fue una organización de origen netamente urbana (Nolte, 1975).

\section{La ciudad se reconstruye: El estilo Republicano ecléctico.}

No se trataba solo de reconstruir la catedral sino también la ciudad en su totalidad. En ese sentido, creemos que existe una clara conexión entre este último suceso y los dos anteriores incendios, para redefinir de manera sistemática la intención de incorporar la ciudad por completo a la modernidad, el progreso y la civilización.

De inmediato se hizo convocatoria pública para realizar la misa campal organizada en el atrio de la asolada catedral y allí fue oportuno invocar el tema de "levantar el templo" y, en ese caso, se trataba de "construir de nuevo una casa soberbia para el Señor que siempre nos ha asistido". La concurrencia al evento fue extraordinaria, tanto de "fieles" como en la recaudación de: "los billetes y monedas, las joyas de las mujeres cayeron en los receptáculos, así como los cheques y promesas entregadas a los sacerdotes, como testimonio admirable de la fe y el ardor religioso de nuestro pueblo" (La Voz de Caldas, 22 de marzo de 1926, p. 1).

Así las cosas, y de acuerdo al entusiasmo con que se congregaron los ciudadanos, la catedral sería la primera obra que se emprendería y se aspiraba "la primera en terminar": era claro también en ese propósito «que la ciudad de Manizales, por ser lo que es, no puede desaparecer». El sitio habitual de la catedral se amplió para la nueva, apropiando toda una manzana, así también era natural pensar en un nuevo modelo de su plano, esto era, "repetir en hormigón armado, el plano de la iglesia destruida con sus dos torres delanteras y su gran ábside" ${ }^{15}$; en ese caso, hubo momentos para la elegía con la cual se pretendía alentar los ideales propiciatorios para la reconstrucción de la iglesia y, por supuesto, no evitaba la insistencia porque se mantuviera la imagen en el nuevo diseño:

La catedral yace en escombros. Sobre su ruina levantará de nuevo la raza invencible un templo grandioso y soberbio que recuerde a las generaciones de fin de siglo que por sobre las tragedias, flotó siempre la fe (...) Erguida y severa en su grandiosa arquitectura moderna, la mueva catedral, de inmensas bóvedas y columnas gigantescas, entre jardines armoniosos, levantará sus torres desafiadoras, sus colosales cúpulas sobre la nueva ciudad magnífica que surgirá de los escombros. (La Voz de Caldas, 24 de marzo de 1926, p. 5).

Se trataba de coincidir en un estilo no solo para la iglesia, sino también para la ciudad en su conjunto, y ello tenía que ver con el estilo Republicano, que ya estaba primando en algunas ciudades de Colombia. Escobar (1997) sostiene que "las transformaciones que comenzaron a multiplicarse en la arquitectura, con motivo de la reconstrucción, han dado la pauta para determinar el patrimonio arquitectónico de la ciudad en ese «estilo»" (pp. 57-58); en efecto, las búsquedas de estilo y de lo bello, se orientaron tomando como referente el Capitolio Nacional (Bogotá), que no era el mejor ni el más bello, pero si ofrecía "las cualidades extraordinarias de solidez y resistencia, sin embargo, la mirada de la élite de Manizales, siempre estuvo orientada "de acuerdo con los dictados del eclecticismo europeo de la segunda mitad del siglo XIX" (Esguerra, 1997, p. 103).

En el caso de la catedral, el edificio símbolo de la ciudad o la imagen de "la fuerza de la fe religiosa", rezumaba las pretensiones de los feligreses en el sentido, cita Esguerra que fuera "una obra grande, bella y arquitectónicamente que llene las aspiraciones de los católicos habitantes del departamento de Caldas (...) parecida a San Pedro en Roma o a la catedral de Colonia" (1997, p. 103). 


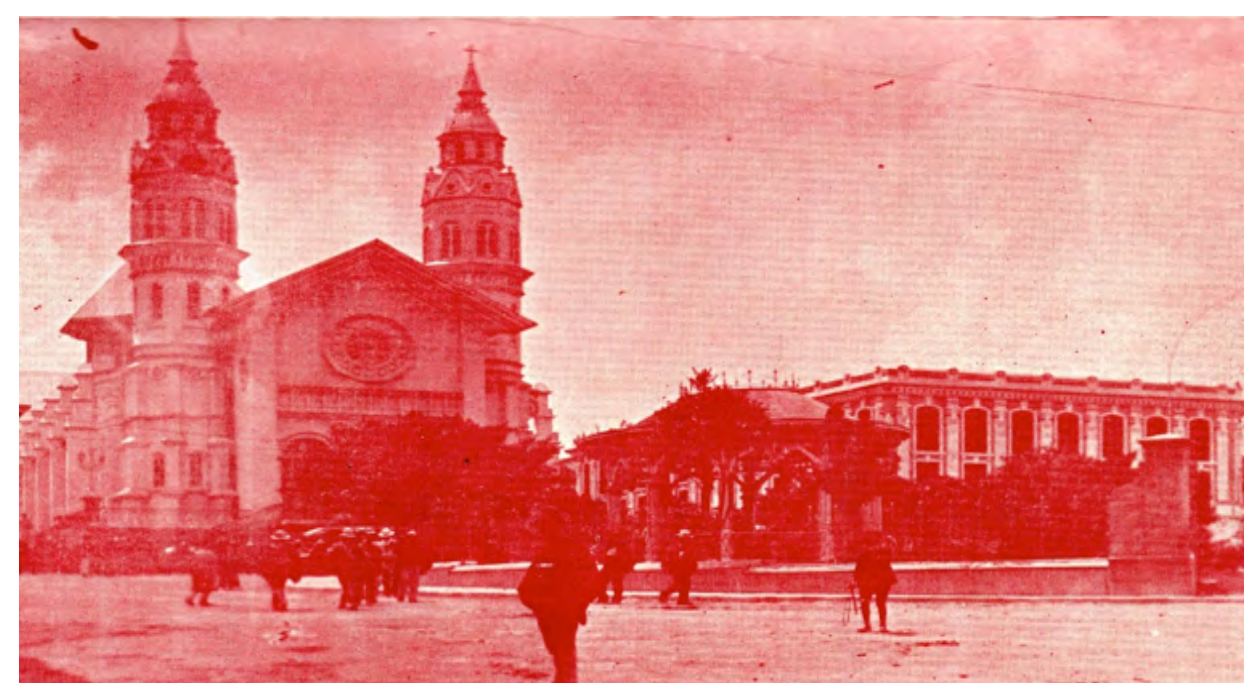

Figura 3. La antigua Iglesia catedral. Imagen tomada de Monografia de Manizales, por J. Gaviria, 1924, p. 72.

A principios de 1927 se hicieron los contactos respectivos en la capital francesa, directamente con la Academia de Bellas Artes a fin de que avalara el concurso de "planos"; se trataba, dice Esguerra (1997), de optar entre el espíritu de la ciudad que recogía el Neo-gótico de J. Polty o el Art- Decó, que planteaba para la época el modernismo, el cual Fabo al cuestionarlo definía como: "la inmoralidad y la impiedad [y] son el vitriolo -léase lo diabólicode la civilización, [pues] enervan las energías del individuo y destruyen las naciones" (1924, p. 291), en un genuis loci como el mismo Fabo define a la ciudad "obra de católicos tradicionalistas, de hombres que creen en Dios, que comulgan frecuentemente y rezan en sus hogares el santo Rosario" (1924, p. 292).

El neo-gótico fue la propuesta que ganó finalmente, considerada para la época como la más apropiada para la casa de Dios, de acuerdo al padre Nazario Restrepo, una autoridad en la materia: "el hálito de la divinidad parece soplar bajo esas bóvedas. Por eso, al ver los planos de Polty se siente instintivamente, deseo de doblar la rodilla" (citado por Esguerra, 1997, p. 109); cabe mencionar que la construcción de la nueva iglesia catedral duró más de diez años, toda ella en concreto armado y tuvo un costo de 1500000 dólares.
No obstante, las pretensiones de la reconstrucción de la ciudad en ese período de los años veinte no se quedaron ahí, pues para julio de 1927, en la zona incendiada, diría el periódico La Voz de Caldas:

Ya se ven edificios, muchos de ellos hermosos, de fachada verdaderamente arquitectónicas, cómodos y elegantes construidos con materiales incombustibles en su mayor parte; luciendo en calles anchas, dándole un aspecto de ciudad moderna y joven que hará honor a la República y será timbre de orgullo de nuestro pueblo enérgico, laborioso y emprendedor. (7 de julio de 1927, p. 4).

De los 219 edificios destruidos en los siniestros de 1925 y $1926^{16}$, se habían construido 46 y, estaban en construcción otros 62 . La nota periodística agrega que se habían otorgado por lo menos 416 permisos para nuevas construcciones, no solo de carácter institucional como el hospital, el orfanato, la estación del ferrocarril, sino también para la construcción de casas en barrios como Vélez, Versalles y Estrada, recién constituidos, y sobre la avenida paralela a la Avenida Cervantes. Luego vinieron otros barrios como Santa Elena, Lleras, Palogrande y La Estrella, que emergían rompiendo el marco de la traza fundacional, según Escobar: "para 


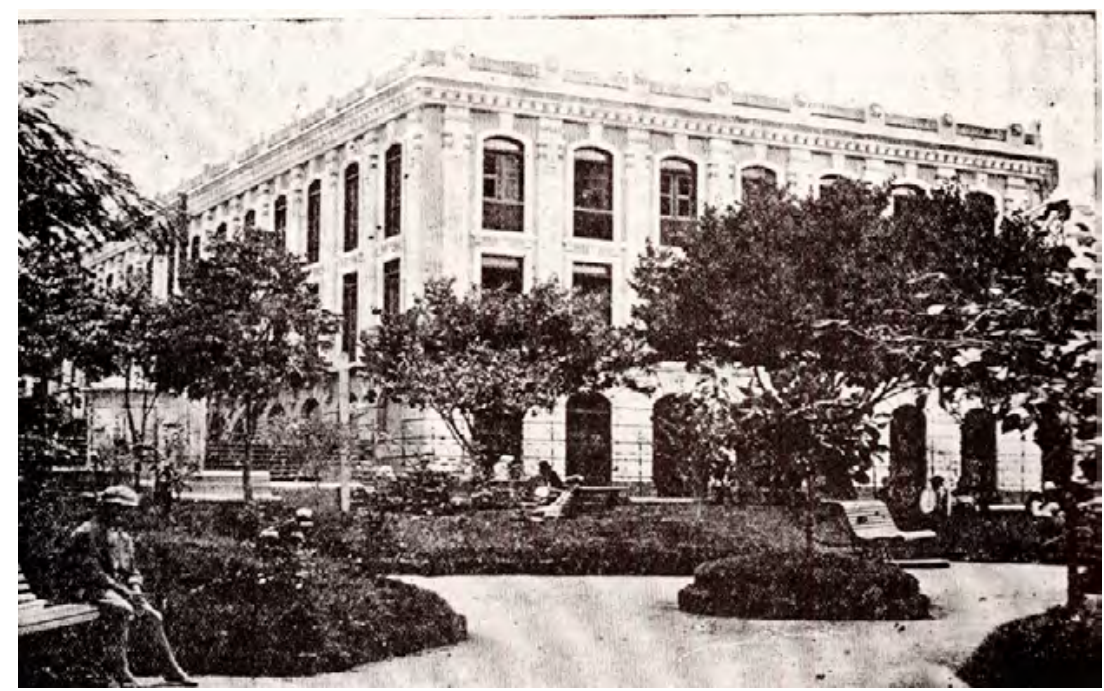

Figura 4. Parque de Bolívar con el Edificio del Banco de Caldas al fondo. Imagen tomada de Historia de la ciudad de Manizales, por P. Fabo de María, 1926, p. 230.

los estratos más altos $\mathrm{y}$, otros, como el barrio Colombia, para quienes eran menos favorecidos por la fortuna" (1997, pp. 63-64). Además del empeño con que participó La Compañía (Ulen) para la reconstrucción de la ciudad, participaron firmas privadas en la construcción de chalets en el recién constituido barrio de Campo-hermoso, todo ello con la incorporación del concreto armado. Llegaba entonces, la "era de las modernas construcciones desafiadoras de la acción del tiempo y de los peligros del fuego y de los terremotos" (La Voz de Caldas, 25 de enero de 1926, p. 7). Uribe sostiene que Manizales fue "de las primeras ciudades del país en emplear el cemento armado" (1984, p. 126), acotando que en el caso de Medellín, también observamos este auge en la construcción, llevado a cabo por la firma H. M. Rodríguez e Hijos, fundada en 1903 (Mejía, 1992).

Lo importante a resaltar ahora, tiene que ver con el papel desempeñado por el cemento armado, para recubrir las estructuras de madera y guadua con el fin de protegerlas de la humedad, a la vez que la plasticidad del material posibilitaba moldearlo con cuanto motivo ornamental propusieran los modelos eclécticos: eclecticismo en tanto las tecnologías construc- tivas y los materiales de todo tipo, ya sean entramados de bahareque o armadura de concreto reforzado o sistemas mixtos. Esto explicaría las posibilidades arquitectónicas, como sugieren Robledo (1997) y Esguerra (1997), para la implementación del estilo Republicano que suprimía los aleros por áticos, logrando definitivamente por medio de la disposición simétrica de los elementos, representar lo más fielmente posible el modelo original; Se erigieron como "edificios de tres y cuatro pisos, modificándose así la escala de apreciación por parte del observador" (Escobar, 1997, pp. 84-85).

Acostumbrados a apreciar y a vivir la ciudad desde la escala humana, esto es, a $170 \mathrm{~cm}$., -la estatura promedio de un hombre, de acuerdo a Le Corbusier-, ahora en esas nuevas condiciones arquitectónicas apoyadas en el cemento u hormigón armado, era claro que la escala humana se modificaría sustantivamente, al plantear, sugiere el mismo Le Corbusier (1978), no solo una nueva sensación o instante arquitectural, como también el crear una síntesis naturaleza- arquitectura, tan majestuosa como inesperada $^{17}$; Burke, entonces, nos dice que "el plano de un edificio moldea la sociabilidad de la gente que lo usa" $(2009$, p. 14). 


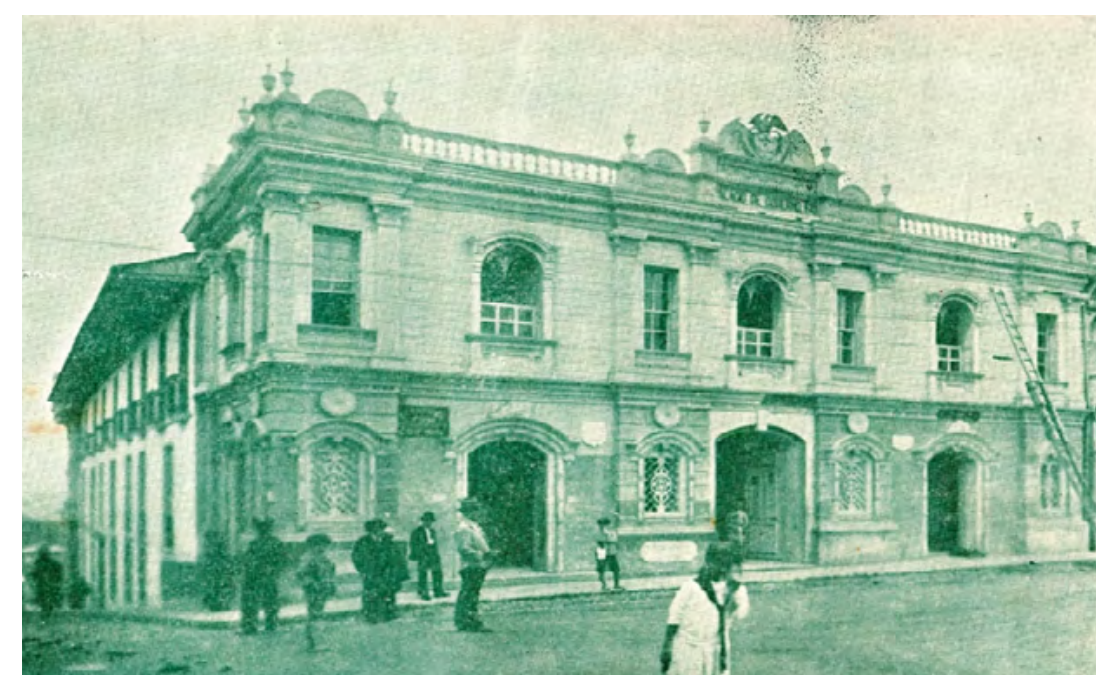

Figura 5. Palacio de Gobierno. Imagen tomada de Monografia de Manizales, por J. Gaviria, 1924, p. 88.

Se construyó entonces el Palacio de la Gobernación, que de acuerdo con lo reseñado en septiembre de 1927 por el periódico La Voz de Caldas, "este gran edificio será un lujo positivo, no solo para Manizales, sino para el país" (citado por Esguerra, 1997, p. 103); también el palacio episcopal, bancos y hoteles, y en lo que respecta al palacio nacional (1928), el cual adicional a su estilo Republicano, se expresaba "renacentista por su cúpula con linterna", además de resaltar el "Gran Olimpia" (1930), con capacidad para 3000 espectadores y con "once puertas de salida para casos de emergencia" (Uribe, 1984, pp. 120; 126).

\section{A modo de cierre}

Como se colige, el auge de la reconstrucción de Manizales a partir del cemento armado produjo transformaciones urbanas, tanto en la ciudad donde se apreció y se vivió de manera distinta, como también transformaciones sociales que se reflejaron en la vivienda urbana; estas últimas no fueron menos importantes; en primer lugar, la relación corredor-calle, dice Giraldo (1991), adquiere su máximo significado plástico, pues la fachada expresa una relación espacial que se traduce en valor a través del estatus social, con la proliferación de balcones en las viviendas; el otro elementos innovador en la vida social de la ciudad, tiene que ver con el uso de los primeros pisos; en efecto, dice Giraldo (1991),

Dejó de ser funcional y económico el uso exclusivo del edificio para una sola familia (...) el primer piso se destinará a la renta, que repercutirá en su espacio (...) nuevos espacios dedicados a actividades de comercio y bodegaje, contemporizando las actividades, revitalizando los edificios en una mayor producción económica y social. (p. 89).

Robledo (1996), adiciona a este nuevo espacio el alquiler "para comercios y talleres o para habitación de familias de artesanos y obreros" (p. 196).

Por su parte, el segundo piso se ha independizado del primero, institucionalizándose "el hall o vestíbulo", lo dice Giraldo M. (1991):

Que va a ser las veces de un claustro cerrado y se va a poder utilizar el espacio central a cualquier hora o clima. El resto de la casa gira en torno a él; (...) es el nuevo espacio público de la casa, el más dinámico, El patio: La plaza de la casa. (p. 89). 


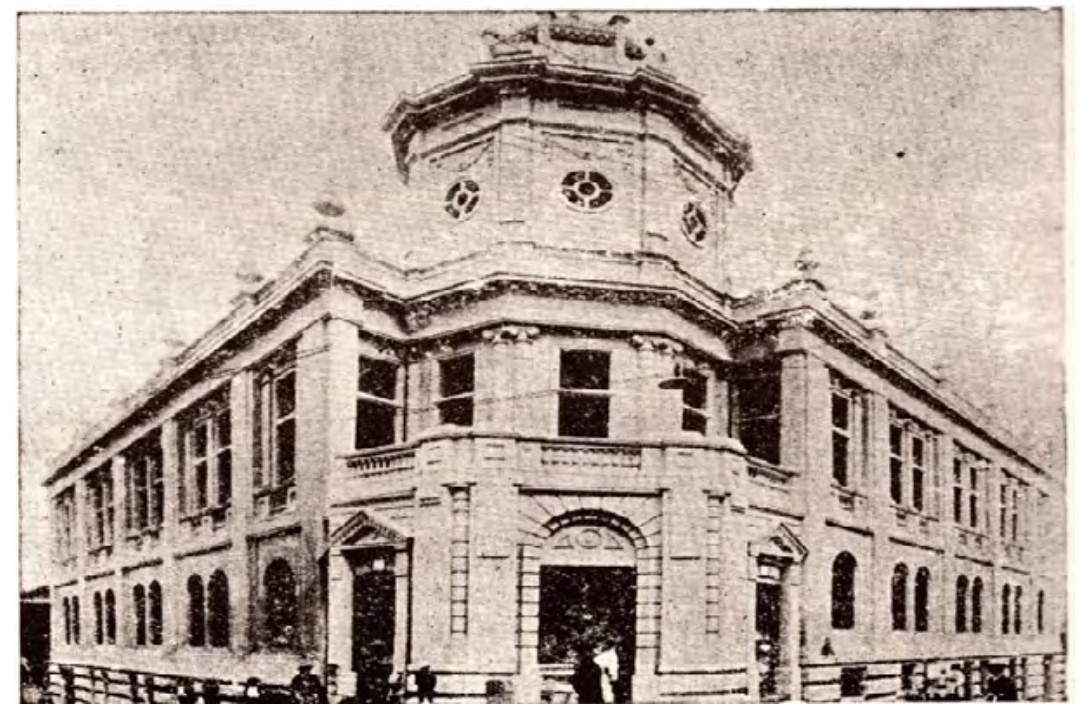

Figura 6. Palacio Municipal. Imagen tomada de Monografia de Manizales, por J. Gaviria, 1924, p. 230.

Robledo (1996), reitera el que la "vida social de la familia propietaria se realizaba en el segundo piso. (...) el patio central desapareció del primer piso y se trasladó al segundo", lo que Rufino Gutiérrez, personaje de la época, citado por Robledo (1996), retraía de este modo:

Los patios, en el nivel superior (...) se han aprovechado (...) para construir sobre ellos lujosos salones de recibo o vestíbulos, y en los más centrales, en la calle del comercio, los patios se han convertido en productivos almacenes en lo bajo. (p. 198).

Ahora bien, más que un contraste dramático, como lo sugiere Burke (2009), a propósito de la historia social, entre las dos partes de la casa, donde la parte baja, estaría "asociada con la naturaleza, la obscuridad, las mujeres, el sexo y la humedad" y la parte alta de la casa asociada "con la cultura, la luz, los hombres, el tejido y los invitados" (p. 14), creemos también que los negocios, en la parte baja de la casa, requerían ser refrendados socialmente en la parte alta, esto es, el nuevo espacio público de la casa.

Por otro lado, las casas de estructuras de madera con techo pajizo a instalaciones más estables en tapia y teja de barro o ramadas de

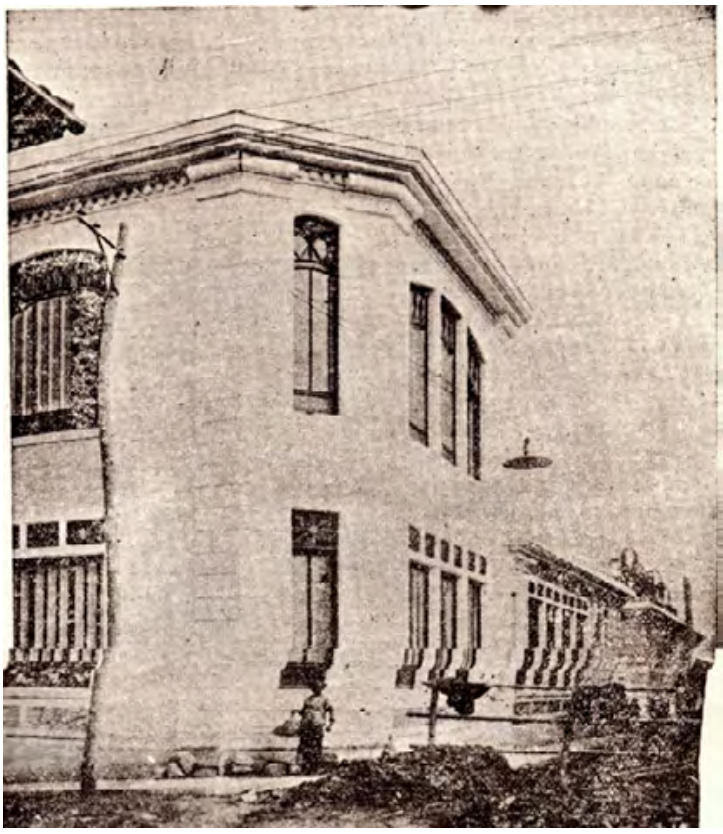

Figura 7. Escuela Modelo. Imagen tomada de Historia de la ciudad de Manizales, por P. Fabo de María, 1926, p. 127.

guadua (también denominados para la época "ranchos de vara en tierra") ${ }^{18}$ : el sistema constructivo era el mismo para todas sin excepción, conformado por armadura de madera y guadua, recubiertos de tierra y cagajón (el tradicional bahareque caldense), reitera Esguerra (1997); este tipo de vivienda no sólo se le resistía al nuevo estilo, sino que también era propiciatoria 
para la humedad, el fuego y los terremotos, en síntesis, la ciudad y sus viviendas connotaban una tipología claustral, empero, hubo ciertamente la "voluntad de estilo", para cambiar la apariencia de las viviendas y edificios.

Con la llegada del cemento, los cambios que se enuncian para la vivienda urbana fueron para las fachadas, las cuales sufrirían dos cambios fundamentales, de un lado: "reemplazar el bahareque de tierra por el metálico, primero y, posteriormente, por el encementado" (Esguerra, 1997, p. 85); de otro lado, los balcones corridos y los anchos aleros: los primeros fueron remplazados poco a poco y sin mayor resistencia por balcones asignados individualmente a las puerta-ventana, con cambios de estilo y de materiales; los segundos, desaparecen no obstante servir de resguardo de la humedad, pero se reemplaza o sustituye por el ático: la vivienda, entonces, aludiendo a Burke, se convertiría en "una de las principales formas de consumo para llamar la atención" (2009, p. 14). Para esto se suele obviar el papel del andén en la nueva fisonomía de la vivienda urbana, al establecer a partir de él una relación distinta entre lo "público y lo privado", pues allí están ubicados "los accesos, el de la vivienda principal se demarca con una especie de postal, diferenciándose de los demás accesos por sus plásticas proporciones" (Giraldo, 1991, pp. 89-90), en una época de "exhibicionismo social", dice Romero, en tanto reclamo de las clases medias y burguesía en aras de constituir un estilo de vida que quiso ser "cosmopolita por oposición a las formas provincianas de vida predominantes hasta entonces" (1984, pp. 282; 284).

\section{Referencias}

Almandoz, A. (2008). Entre libros de historia Urbana. Para una historiografía de la ciudad y el urbanismo en América Latina. Caracas, Venezuela: Editora Equinoccio/ U. Simón Bolívar.
Argan, G. (1984). Historia del Arte como historia de la ciudad. Barcelona, España: Editorial Laia.

Bardet, G. (1961). El Urbanismo. Buenos Aires, Argentina: EUDEBA.

Botero, F. (1996). Medellín 1890-1950, Historia Urbana y juego de intereses. Medellín, Colombia: Editorial Universidad de Antioquia.

Colmenares, G. (1998). Ricardo Rendón: Una fuente para la historia de la opinión pública. Bogotá, Colombia: Tercer Mundo Editores.

Burke, P. (2009). Historia social y cultural de la casa. Historia Crítica, (39), 11-19.

Contardi, B. (1984). Prólogo. En G. C. Argan, Historia del Arte como historia de la ciudad. Barcelona, España: Editorial Laia.

Correa R., J., y Martínez, C. H. (2010). Progreso, moral y civilización. La preocupación higienista en la Sociedad de Mejoras Públicas de Manizales (Colombia); primera mitad del siglo XX. Revista Gestión \& Región, (10), 7-28.

Escobar, J. (1997). Transformaciones Urbanas. En M. Santander y J. E. Arango (Eds.), Arquitectura Republicana en Manizales. Manizales, Colombia: Editorial Nomos.

Esguerra, J. (1997). Construcción de una imagen de prosperidad 1905-1935. En M. Santander y J. E. Arango (Eds.), Arquitectura Republicana en Manizales. Manizales: Editorial Nomos.

Fabo de María, P. (1926). Historia de la ciudad de Manizales. Manizales, Colombia: Mario Camargo y Cía., T. I y II.

Gaviria T., J. (1924). Monografía de Manizales. Manizales, Colombia: Editores Mario Camargo \& Co. 
Ginzburg, C. (1989). Mitos, Emblemas, Indicios. Morfología e Historia. Barcelona, España: Editorial Gedisa S. A.

Giraldo M., H. (1991). Aproximación de Manizales en la Arquitectura nacional colombiana 1848-1925. Manizales, Colombia: Universidad Nacional de Colombia.

González C., J. (2006). De la ciudad al territorio. La configuración del espacio urbano en Ibagué 1886-1986. Ibagué, Colombia: Universidad del Tolima.

Harvey, D. (2004). La condición posmoderna. Investigación sobre los orígenes del cambio cultural. Buenos Aires, Argentina: Amorrortu Editores.

Kalmanovitz, S. (1999). Economía y Nación. Una breve historia de Colombia. Bogotá, Colombia: Tercer Mundo Editores.

Le Corbusier. (1978). Precisiones respecto a un estado actual de la arquitectura y del urbanismo. Barcelona, España: Editorial Poseidón.

Mejía P., G. (2000). La Historia urbana y la valoración del patrimonio urbano. Revista Javeriana, 134(664).

Nolte, E. (1975). El Fascismo de Mussolini a Hitler. Barcelona, España: Plaza \& Janes, S. A.

Ocampo, J. (1972). Dominio de clase en la ciudad colombiana. Medellín, Colombia: Editorial Oveja Negra.

Payne, S. (1995). Historia del Fascismo. Barcelona, España: Editorial Planeta, S. A.

Robledo C., J. (1996). La Ciudad en la colonización antioqueña: Manizales. Bogotá, Colombia: Editorial Universidad Nacional.

Robledo C., J. (1997). Arquitectura Republicana, iy de bahareque!. En M. Santander y J. E. Arango (Eds.), Arquitectura
Republicana en Manizales. Manizales, Colombia: Editorial Nomos.

Romero, J.(1984). Latinoamérica: Las ciudades y las ideas. México D.F., México: Siglo XXI Editores.

Tuan, Y. (2007). Topofilia. Un estudio de las percepciones, actitudes y valores sobre el entorno. Barcelona, España: Editorial Melusina.

Tirado M., Á. (1995). Aspectos políticos del primer gobierno de Alfonso López Pumarejo (1934-1938). Bogotá, Colombia: Planeta colombiana S. A.

Uribe, C. (1984). Los Años veinte en Colombia. Ideología y Cultura. Bogotá, Colombia: Ediciones Aurora.

Urrego, M. (1997). Sexualidad, Matrimonio y Familia en Bogotá 1880- 1930. Bogotá, Colombia: Editorial Planeta/ CIUD.

Valencia, A. (1990). Manizales en la dinámica colonizadora (1846-1930). Manizales, Colombia: Fondo Editorial U. de Caldas.

Valencia, A. (1997). La Edad de Oro. En M. Santander y J. E. Arango (Eds.), Arquitectura Republicana en Manizales. Manizales, Colombia: Editorial Nomos.

\section{Notas}

${ }^{1}$ Se vio la necesidad de ampliar las calles en un metro con cincuenta en cada uno de los costados, de tal forma que los vehículos pudieran circular más fácilmente"; también estaba en curso para aprobación como Acuerdo, el proyecto sobre reglamentación de vehículos "dado el número (...) que cada día es aumentado por un nuevo elemento. Serán señaladas las calles por donde han de transitar los autos, las que han de seguir los carros y autocamiones y por fin las vías que han de recorrer los coches, los cuales sufrirán también la vigilancia estricta de la policía en lo que atañe al manejo de los 
caballos, el trato de las aurigas, etc.", "Sobre Locomoción”, La Patria [Manizales], 24 de mayo, 1922, p. 1.

${ }^{2}$ Subrayado propio.

${ }^{3}$ Para 1926, la capital departamental contaba con 57817 ha., y si bien Pereira le seguía con 36156 ha., el municipio de Calarcá, vecino a Armenia, contaba con mayor población que aquélla, 38250 ha.; La Voz de Caldas [Manizales], 7 de julio de 1927, p. 5.

${ }^{4}$ No obstante, dicen Correa y Martínez, que para esos años, el filme no esconde una sociedad dual, pues por un lado aparece "el testimonio de una sociedad rica y lujosa", pero también se expresa una "sociedad campesina"; Progreso, moral y civilización", p. 19; Oscar I. Salazar A., "La Cara pública y la cara vergonzante. Imágenes de la urbanización de Bogotá en la ciudad fílmica y la fotografía urbana de mediados del siglo $X X$ ', en Bogotá filmica. Ensayos sobre cine y patrimonio cultura (Bogotá, Alcaldía Mayor de Bogotá, 2012), pp. 117-118.

5 Se trataba del ministro de Hacienda y Crédito Público, Jesús María Marulanda, quien estuvo en compañía del ministro de Obras Públicas, Laureano Gómez; La Voz de Caldas [Manizales], 19 de enero, 1926, p. 1.

${ }^{6}$ El trazado en lo que corresponde a Caldas, era Puerto Caldas- Cartago- Pereira, y se estimó en \$1 950 000; La Patria, [Manizales], agosto 6, 1921, p. 1; para la época el peso colombiano estaba "pegado" a la divisa norteamericana, es decir, a la par con el dólar; Salomón Kalmanovitz, Economía y Nación. Una breve historia de Colombia (Bogotá: Tercer Mundo Editores, 1999, p. 248).

7 Precisar, de acuerdo a Esguerra (1997), que Aquilino Villegas "y otros 40 damnificados no esperaron a que la empresa gringa comenzara con gran parsimonia los trabajos, sino que confiaron la construcción de sus viviendas a los ingenieros y maestros de obra manizaleños" (p. 95).

${ }^{8}$ Esguerra (1997), sostiene que la Ulen no fue propiamente la que inicio "la era del concreto armado en la ciudad", sino el ingeniero José María Gómez quien asociado con el belga Félix Kleebauer, trajo la primera trituradora para la construcción del matadero en 1924" (p. 95); empero, admite que "La Compañía" desarrolló "los trabajos comunales más grandes -acueductos y alcantarillados modernos-", construyendo también "los principales edificios de la ciudad, entre ellos los palacios de la gobernación y nacional y la estación del ferrocarril" y a ella estuvieron como interventor el arquitecto Pablo de la Cruz y Benjamín Dussan Canals, y no solo colombianos sino también extranjeros de origen francés, italiano y, por supuesto, norteamericano, que augurarían momentos importantes de la construcción y la arquitectura en Colombia; (pp. 95-96); Uribe C. se refiere a "La Casa Ullen", imprecisamente como firma inglesa (1984, p. 126).

${ }^{9}$ Los estimativos posteriores a la tragedia muestran que las pólizas cubrirían por lo menos seiscientos cincuenta mil pesos (\$650000) y la dotación de la Iglesia catedral parece que se pudo recuperar al momento del siniestro; La Voz de Caldas [Manizales] 24 de marzo, 1926, p. 1.

${ }^{10}$ También llegó a inculparse, como fuera habitual en la década, a "las empresas de luz y de energía eléctrica"; "Medidas preventivas y Cuerpo de Bomberos", La Voz de Caldas [Manizales] 22 de marzo, 1926, p. 1.

11 "Como la autoridad tomó sospechas de algunos individuos los condujo, muy acertadamente a la prisión"; "Un nuevo incendio amenaza destruir la ciudad", La Voz de Caldas [Manizales] 23 de marzo de 1926, pp. 3, 6 . 
${ }^{12}$ La "Liga", estaba integrada sustantivamente por comerciantes, de acuerdo a lo que menciona Valencia que para la época representaba a "78 casas comerciales mayoristas", (1997, p. 41)

${ }^{13}$ Integraban el equipo del cuerpo de bomberos, un sargento, un cabo, cuatro bomberos así como de sus funciones correspondientes; "Medida de seguridad", Editorial, La Voz de Caldas [Manizales] 26 de marzo, 1926: 1.

14 "Protectores del Proletariado", Editorial, La Patria [Manizales] 28 de abril, 1922, p. 1; véase también "Un bolsevique [sic] auténtico”, La Patria [Manizales] 31 de mayo, 1922, p. 1; para una mirada sintética sobre los temas por los cuales llegaron a dividirse y confrontar los partidos Liberal y conservador en el siglo XIX y XX, Ch. Bergquist, Los Trabajadores en la historia latinoamericana. Estudios comparativos de Chile, Argentina, Venezuela y Colombia (Bogotá: Siglo Veintiuno Editores, 1988), 310-339.

${ }^{15}$ Con diseño de Mariano Santamaría se construyó, entre 1888 y 1893, la iglesia principal, en la que se pueden reconocer algunos elementos de "estilo", dice Robledo C. (1996), refiriéndose a la primera catedral de la ciudad, "a pesar de que se edificó con la tecnología sui géneris del bahareque metálico" (p. 190); "Nuevos detalles del incendio del sábado”, La Voz de Caldas [Manizales] 22 de marzo, 1926, p. 1.
${ }^{16}$ Esguerra menciona 250 edificios, (1997, p. 90); Valencia habla de 229 edificios destruidos en el incendio de 1925 y 20 edificios en 1926 (1997, pp. 49-50).

${ }^{17} \mathrm{Si}$ bien Le Corbusier está proponiendo en esos años una arquitectura más funcional y menos referida al esteticismo que plantea el estilo Republicano, ello no invalida las nuevas sensaciones de habitar la ciudad que plantea este estilo; Precisiones respecto a un estado actual de la arquitectura y del urbanismo (Barcelona: Editorial Poseidón, 1978, pp. 82; 95; 122).

${ }^{18}$ Escobar (1997, p. 56); la expresión "ramadas de guadua" es de A. Villegas, refiriéndose a los edificios destruidos en la conflagración de 1925; La Voz de Caldas [Manizales] 28 de enero, 1926, p. 1. 